\begin{tabular}{|c|c|c|}
\hline $\begin{array}{l}\text { JURNAL } \\
\text { INOVASI } \\
\text { TEKNOLOGI } \\
\text { PENDIDIKAN }\end{array}$ & $\begin{array}{l}\text { Jurnal Inovasi Teknologi Pendidikan } \\
\text { Volume 5, No 1, April } 2018 \text { (70-81) } \\
\text { Online: http://journal.unv.ac.id/index.php/iitp }\end{array}$ & 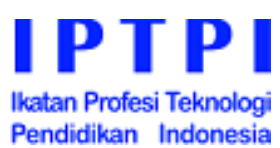 \\
\hline
\end{tabular}

\title{
PENGEMBANGAN E-BOOK INTERAKTIF MATA PELAJARAN TEKNOLOGI INFORMASI DAN KOMUNIKASI (TIK) UNTUK SMK KELAS X
}

\author{
Muhammad Ihsaan Fathoni ${ }^{1 *}$, Eko Marpanaji ${ }^{2}$ \\ 1 Universitas Mercubuana Yogyakarta \\ 2Universitas Negeri Yogyakarta \\ Jl Jembatan Merah No.84C, Soropadan, Condongcatur, Depok, Sleman, Yogyakarta 55281 \\ 2Jl. Colombo No. 1, Depok, Sleman 55281, Yogyakarta, Indonesia \\ * Corresponding Auhtor. Email: ihsaan.fathoni@gmail.com
}

\begin{abstract}
Abstrak
Penelitian ini bertujuan untuk: (1) mendeskripsikan pengembangan produk media pembelajaran e-book interaktif TIK yang layak pada peserta didik kelas X SMK N 2 Yogyakarta, dan (2) mengetahui efektifitas produk media pembelajaran $e$-book interaktif TIK terhadap hasil belajar peserta didik kelas X SMK N 2 Yogyakarta.Penelitian pengembangan ini mengacu langkah yang dikembangkan oleh Alessi \& Trollip. Prosedur pengembangan terdiri dari dari tiga fase, yaitu perencanaan, desain, dan pengembangan. Pengumpulan data dilakukan menggunakan lembar validasi produk untuk ahli media, lembar validasi produk untuk ahli materi, kuisioner untuk pengguna, dan tes hasil belajar. Teknik analisis data menggunakan teknik deskriptif kualitatif dan kuantitatif.Hasil penelitian menunjukkan bahwa media pembelajaran $e$-book interaktif TIK dinilai sangat baik yang diperoleh melalui uji alpha dan uji beta, sehingga layak digunakan sebagai sumber belajar peserta didik. Uji efektivitas menunjukkan bahwa penggunaan media pembelajaran e-book interaktif TIK lebih efektif daripada pembelajaran TIK biasa. Rerata $\mathrm{N}$-gain antara kelas eksperimen dan kelas kontrol menunjukkan bahwa nilai nilai kelas eksperimen lebih tinggi daripada kelas kontrol dan berbeda secara signifikan.
\end{abstract}

Kata kunci: TIK, e-book, interaktif

\section{DEVELOPING INTERACTIVE E-BOOK ON INFORMATION AND COMMUNICATION TECHNOLOGY (ICT) LESSON FOR $10^{\text {th }}$ GRADE OF VOCATIONAL HIGH SCHOOL}

\section{This study aimed to: (1) describe the development of instructional media products based on} appropriate ICT interactive e-book on students for $10^{\text {th }}$ grade of SMKN 2 Yogyakarta, and (2) to know the effectiveness of ICT interactive e-book based learning e-book products on participants' learning outcomes for $10^{\text {th }}$ grade of SMKN 2 Yogyakarta. This development research refers to the steps developed by Alessi \& Trollip. The development procedure consisted of three phases, namely planning, design, and development. Data collection was performed using product validation sheets for media experts, product validation sheets for material experts, questionnaires for users, and learning result tests. The data analysis techniques used qualitative and quantitative descriptive techniques. The result of the research showed that ICT interactive e-book learning media was very good which was proved through alpha test and beta test, so it was suitable to be used as a learning resource for learners. The effectiveness test showed that the use of interactive ICT e-book learning media was more effective than regular ICT learning. The mean N-gain between the experimental class and the control class indicated that the value of the experiment class grade was higher than the control class and differed significantly.

Keywords: ICT, e-book, interactive

Permalink/DOI: http://dx.doi.org/10.21831/jitp.v5i1.17149 


\section{Pendahuluan}

Kemajuan di bidang teknologi dan ilmu pengetahuan membawa perubahan di segala aspek, tidak terkecuali dalam dunia pendidikan. Dunia pendidikan memerlukan strategi yang tepat dengan memperhatikan komponen-komponen diantaranya seperti metode, materi, sarana dan prasarana, maupun evaluasi supaya tercapai sesuai tujuan. Dalam dunia pendidikan dikenal suatu metode pembelajaran yang dapat disajikan dengan menggunakan suatu alat peraga yang biasa disebut sebagai media pembelajaran agar materi yang disajikan selalu atraktif dan menarik. Salah satunya dengan memanfaatkan teknologi komputer sebagai sarana untuk membuat maupun mengembangkan media pembelajaran. Perkembangan perangkat lunak maupun perangkat keras tentunya sangat mendukung terciptanya suatu media pembelajaran berbasis multimedia. Dengan multimedia tentunya dapat disajikan media pembelajaran yang memuat gambar (picture), suara (audio), dan tulisan (text).

Teknologi Informasi dan Komunikasi (TIK) sebagai bagian dari ilmu pengetahuan dan teknologi (IPTEK) secara umum adalah semua yang teknologi berhubungan dengan pengambilan, pengumpulan (akuisisi), pengolahan, penyimpanan, penyebaran, dan penyajian informasi (Rusman, Deni Kurniawan, \& Cepi Riyana, 2013, p. 88). Mata pelajaran Teknologi Informasi dan Komunikasi merupakan salah satu mata pelajaran yang dipelajari di SMK dan sederajat khususnya untuk jurusan multimedia. Mata pelajaran TIK memiliki peranan penting dalam meningkatkan kemampuan siswa dalam bidang teknologi khususnya bidang komputer sebagai alat teknologi dan informasi. Melihat jelasnya fungsi ma-ta pelajaran TIK terhadap perkembangan era komunikasi yang berkembang pesat, seharusnya siswa mempunyai ketertarikan dan minat yang tinggi pada mata pelajaran TIK. Mata pelajaran TIK bersifat teori dan praktek yang didalamnya terdapat banyak materi yang masih terdengar asing sehing- ga jika tidak dikemas dalam suatu buku maupun media pembelajaran yang menarik, siswa akan sulit dalam memahami dan mempelajari.

Multimedia pembelajaran sebagai suatu media atau perantara seharusnya dikemas secara baik dan efektif dalam konteks penyampaian pesan agar dapat menjembatani antara sumber informasi (pendidik) dengan penerima (peserta didik). Komunikasi menjadi jembatan atau media penghubung antara pendidik dan peserta didik. Terjadinya kendala dalam komunikasi tersebut menjadi penghambat bagi peserta didik untuk mendapatkan proses belajar yang sebenarnya yaitu berupa pemahaman sehingga pembelajaran lebih bernilai.

Menurut Sujarwo (2011) belajar merupakan proses membangun pengetahuan melalui proses mencari, menemukan, dan menyusun informasi baru hingga mendapatkan makna baru. Belajar merupakan proses yang terjadi terus menerus dan tidak terbatas pada usia, waktu, bahkan subjek yang dipelajari. Rendahnya belajar dan motivasi peserta didik pada umumnya terjadi akibat adanya rasa tidak tertarik atau menganggap kurang bermanfaatnya materi pembelajaran bagi peserta didik ter-sebut. Kurangnya ketertarikan peserta di-dik terhadap materi pembelajaran TIK pa-da dasarnya akibat banyaknya materi dan istilah sehingga terkadang dalam penyampaian materi pembelajaran oleh guru sulit untuk diterima. Maka masalah lanjutan yang harus siap dihadapi adalah peserta didik tidak dapat fokus dalam pelajaran yang disebabkan oleh sulitnya materi yang diterima ketika disampaikan oleh guru. Demi mempetahankan fokus peserta didik, maka diperlukan model pembelajaran yang variatif sehingga tercipta iklim proses pembelajaran lebih menarik. Oleh karena itulah diperlukan sebuah sumber belajar atau media pembelajaran yang tidak hanya menarik secara kemasan, namun harus menarik secara isi atau konsep materi. Dengan demikian diperlukan multimedia yang menarik serta mudah dioperasikan oleh guru 
maupun peserta didik untuk mengatasi masalah tersebut.

Proses pembelajaran identik dengan proses komunikasi yang akan lebih baik jika dalam pembelajaran perlu dibuat me-dia sebagai alat bantu siswa untuk belajar. Selain itu media juga dapat diperlukan sebagai alat untuk menyampaikan pesan yang berupa materi pelajaran kepada siswa. Media yang digunakan dalam pembelajaran di sekolah harus disesuaikan agar pemahaman siswa bertambah dan sebagai pembentuk kreativitas siswa. Salah satu kebutuhan pokok dalam bidang pendidikan adalah ketersediaan buku dan pustaka. Dengan membaca buku, wawasan pengetahuan menjadi luas dan terbuka lebar. Perbaikan kualitas buku dikembangkan seiring kemajuan dibidang ilmu pengetahuan dan teknologi maupun TIK. Oleh karena itu, salah satu jenis media yang mempunyai potensi untuk meningkatkan kreativitas dan pemahaman pengetahuan belajar siswa adalah teknologi media pembelajaran berbasis e-book.

E-book merupakan singkatan dari electronic book atau buku elektronik yaitu buku teks yang dikonversi menjadi format digital. Menurut Shiratuddin, Landoni, Gibb, \& Hassan (2003) e-book juga mempunyai pengertian sebagai lingkungan belajar yang memiliki aplikasi yang mengandung database multimedia sumber daya instruksional yang menyimpan presentasi multimedia tentang topik dalam sebuah buku. Beberapa e-book memang telah beredar dimasyarakat, akan tetapi penyajian $e$ book tersebut masih kurang menarik. Penyajian masih berupa jiplakan dari buku cetak tanpa adanya penambahan kualitas layout yang menarik dan unsur multimedia yang masih minim. Kurangnya pemanfaatan teknologi sebagai suatu media pembelajaran di masa sekarang ini mengakibatkan daya tarik pembelajaran menjadi rendah. Hal ini mengakibatkan kurang tingginya semangat peserta didik untuk belajar. Rendahnya semangat belajar para peserta didik memicu lemahnya penguasaan mereka terhadap ilmu dan teknologi yang seha- rusnya dimiliki dalam membangun dan mengembangkan bangsa tercinta ini.

E-book mulai muncul akibat dari perkembangan teknologi perangkat komputer dan teknologi internet pada kondisi yang sudah berkembang pesat pada masa sekarang ini. Semua jenis konten yang memanfaatkan perangkat komputer maupun smartphone mulai sedikit demi sedikit beralih ke konsep digital yang akhirnya memunculkan sebuah produk baru yang sering dikenal dengan elektronik konten. Berbagai kegiatan sudah bisa dilakukan secara digital seperti mengerjakan tugas kuliah, mengirim pekerjaan kantor dan berbelanja. Sistem digital juga tidak lepas dari sebuah format data standar yang telah ditentukan. Dalam sebuah pengembangan produk digital seperti $e$-book, format data standar berdampak pada dibuatnya teknologi perangkat pembaca seperti $e$-book tersebut.

Pemanfaatan teknologi media pembelajaran berbasis e-book merupakan salah satu solusi dimana pada era sekarang ini perkembangan gadget dalam bentuk smartphone sedang meningkat. Pemanfaatan $e$ book dalam dunia pendidikan akan membawa beberapa keuntungan antara lain: menghemat waktu proses belajar mengajar, mobilitas penggunaan yang bisa diakses kapan dan dimanapun, dan menumbuhkan kemandirian siswa dalam menggali dan mempelajari ilmu pengetahuan.

SMK N 2 Yogyakarta merupakan sekolah yang memasukkan mata pelajaran TIK yang salah satunya adalah Perakitan Komputer dalam kurikulum sekolahnya. Hasil observasi di kelas X SMK N 2 Yogyakarta serta wawancara kepada Guru TIK mata pelajaran Perakitan Komputer adalah peserta didik memiliki motivasi belajar yang rendah ketika belajar sehingga suasana yang terbentuk pada pembelajaran kurang bermakna sehingga pemahaman menjadi rendah serta sulit mencapai tingkatan berpikir kritis. Metode pembelajaran yang digunakan oleh guru TIK di SMK N 2 Yogyakarta sebenarnya sudah secara rinci dan konstektual, yaitu guru sudah menyampaikan teori dan juga praktek dalam pem- 
belajarannya. Akan tetapi, guru masih terlihat dominan dalam proses belajar mengajar, sehingga pendekatan yang digunakan masih Learner Centered Approach. Sumber belajar yang digunakan pun masih menggunakan teks book dan lembar LKS.

Dengan diterapkannya media pembelajaran berbasis $e$-book interaktif ini diharapkan mempermudah pemahaman materi oleh siswa dalam mempelajari mata pelajaran TIK. Media yang dikemas secara visual menarik dan dapat dipelajari kapan dan dimanapun tentunya akan menambah ketertarikan minat siswa dalam belajar.

Berdasarkan uraian yang telah disampaikan tersebut maka penelitian ini bertujuan untuk: (1) menghasilkan produk media pembelajaran e-book interaktif TIK yang layak pada peserta didik kelas X SMK N 2 Yogyakarta; (2) mengetahui efektivitas produk media pembelajaran e-book interaktif TIK terhadap hasil belajar peserta didik kelas X SMK N 2 Yogyakarta.

\section{Metode Penelitian}

Model pengembangan yang digunakan dalam penelitian ini adalah model pengembangan oleh Alessi \& Trollip (2001) yang terdiri dari tiga tahap yaitu planning, design, dan development yang dalam setiap tahapan tersebut dilakukan standard, ongoing evaluation, dan project management. Prosedur penelitian ini meliputi 2 aspek yaitu aspek pengembangan sampai dihasilkan produk multimedia pembelajaran dan aspek pengujian untuk mengetahui efektivitas dan kelayakan produk e-book interaktif yang dikembangkan.

Sebelum melakukan pengembangan untuk menentukan karakteristik materi yang akan dibuat progam dilakukan analisi kebutuhan. Analisis ini mengacu pada penggunaan kurikulum pada sekolah jenjang SMK. Penelitian ini dilaksanakan selama bulan Juni 2016 hingga Maret 2017. Lokasi yang digunakan dalam penelitian ini yaitu SMK N 2 Yogyakarta yang terle-tak di jalan AM Sangaji No 47, Yogyakarta.
Subjek yang digunakan dalam penelitian pengembangan ialah sebanyak tigakelompok, diantaranya satu kelompok untuk uji beta dan dua kelompok dalam uji coba produk untuk perbandingan hasil belajar Subjek uji coba dalam penelitian pengembangan yang dilakukan ini yaitu: dua orang ahli materi dan dua ahli media pada alpha test atau uji alfa, kemudian 26 peserta didik SMK kelas $X$ pada beta test atau uji beta, sedangkan untuk uji efektivitas digunakan dua kelas, diantaranya ialah kelas X-MM1 sebagai kelas eksperimen dan kelas X-MM2 sebagai kelas kontrol.

Seperti yang diutarakan sebelumnya tadi, Model penelitian dan pengembangan Alessi \& Trollip (2001, p. 410) mempunyai tiga atribut (three attributes) dan tiga fase (three phases). Tiga atribut yang dimaksud adalah (1) standards, hal-hal penting yang diperhitungkan untuk menentukan kualitas produk, baik ditetapkan oleh pengembang maupun dari klien, (2) ongoing evaluation, evaluasi yang dilakukan secara terus-menerus selama proses pengembangan berdasarkan standar yang telah ditetap-kan tersebut, dan (3) project management, pengaturan terhadap berbagai sumber, seperti Selanjutnya tiga fase yang dimaksud dalam penelitian dan pengembangan menggunakan model Alessi \& Trollip adalah perencanaan (planning), desain (design), dan pengembangan (development). Diagram model pengembangan multimedia pembelajaran Alessi \& Trollip disajikan pada Gambar 1.

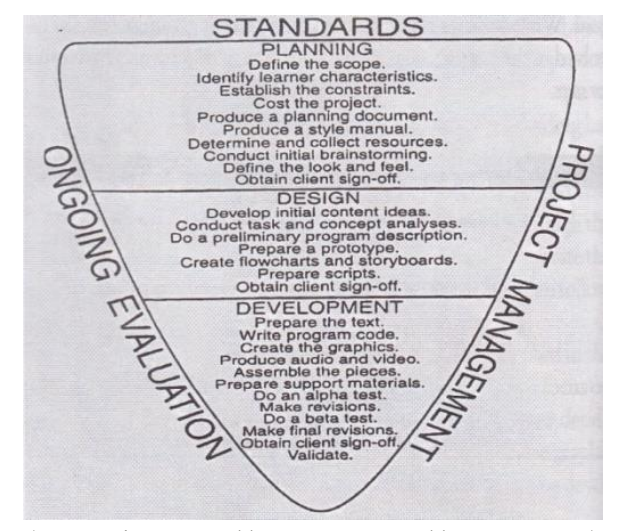

(Sumber: Allesi \& Trollip, 2001)

Gambar 1. Model Alessi dan Trollip 
Model adaptasi yang digunakan dalam penelitian pengembangan ini berdasarkan model pengembangan Alessi \& Trollip berupa penyesuaian penggunaan langkah-langkah pengembangan agar sesuai dengan konteks pembelajaran. Pada tahap perencanaan (planning) dalam penelitian dan pengembangan ini dilakukan beberapa langkah diantaranya ialah (1) mendefinisikan bidang/ruang lingkup, (2) mengidentifikasi karakteristik peserta didik, (3) menentukan dan mengumpulkan sumber-sumber, (4) melakukan brainstroming. Pada tahap desain (design) dilakukan beberapa langkah diantaranya ialah (1) melakukan analisis konsep dan tugas, (2) mengembangkan flowchart dan storyboard, (3) evaluasi dan revisi. Pada tahap pengembangan (development) dilakukan langkah-langkah yang diantaranya ialah (1) menyiapkan teks, (2) membuat grafis, (3) menggabungkan bagian-bagian, (4) menyiapkan materi pendukung, (5) melakukan uji alpha (alpha test), (6) membuat revisi, (7) melakukan uji beta (beta test), (8) membuat revisi akhir, dan (9) evaluasi sumatif.

Instrumen yang digunakan untuk mengumpulkan data berupa instrumen pe nilaian untuk menilai produk yang telah dikembangkan. Instrumen yang dikemangkan dan digunakan dalam penelitian ini meliputi: kuesioner untuk ahli materi, kuesioner untuk ahli media, kuesioner untuk pengguna, serta soal pretest dan posttest.

Data yang diperoleh melalui instrumen penilaian pada saat uji coba berupa data kuantitatif dan kualitatif. Data kualitatif ialah data yang diperoleh dari ahli materi, ahli media, dan pengguna berupa tanggapan, saran, dan masukan terhadap multimedia pembelajaran e-book interaktif TIK yang dianalisis menggunakan teknik deskriptif kualitatif. Analisis ini dimaksudkan untuk menggambarkan karakteristik data pada setiap variabel, sehingga diharapkan akan mempermudah memahami data untuk proses analisis selanjutnya. Hasil analisis data digunakan sebagai dasar untuk merevisi produk yang dikembangkan.
Data kuantitatif diperoleh dari angket penilaian terhadap multimedia e-book interaktif TIK yang telah dikonversikan ke dalam angka menggunakan skala Likert dari ahli media, ahli materi, maupun pengguna seperti penelitan yang telah dilaksanakan Surahman \& Surjono (2017, p. 28). Data tersebut kemudian dianalisis dengan teknik deskriptif kuantitatif yaitu memberikan penjelasan secara mendalam dan objektif berdasarkan data kuantitatif yang diperoleh. Data yang diperoleh dengan menggunakan skala Likert berupa data ordinal sehingga sifatnya adalah urutan yang tidak dapat dipisahkan, tetapi tidak dapat diasumsikan bahwa makna antara setuju dengan sangat setuju adalah sama. Penilaian setiap aspek pada produk yang dikembangkan dalam penelitian ini dengan menggunakan skala Likert dengan skala "5", dikatakan layak apabila nilai yang diperoleh dari responden adalah minimal 4 atau berkategori baik. Skor dan kriteria pada skala Likert dalam penelitian disajikan pada Tabel 1.

Tabel 1. Kriteria Penilaian kelayakan Berskala 5

\begin{tabular}{cc}
\hline Nilai & Kategori \\
\hline$X>4,0$ & Sangat Baik \\
$3,34<X \leq 4,0$ & Baik \\
$2,26<X \leq 3,34$ & Cukup \\
$1,99<X \leq 2,26$ & Kurang \\
$X \leq 1,99$ & Sangat kurang \\
\hline
\end{tabular}

Sumber (Sudijono, 2013, p. 329)

Efektivitas e-book interaktif mata pelajaran TIK diperoleh melalui hasil uji statistik hasil belajar peserta didik yaitu pretest dan posttest yang diselenggarakan pada kegiatan uji coba. Analisis data dilakukan dengan melakukan pengujian hipotesis dari hasil eksperimen berdasarkan uji coba yang telah dilakukan.

Data yang digunakan dalam menguji hipotesis ini adalah skor $N$-gain kelompok eksperimen dan kelompok kontrol. Menurut Hake (Meltzer, 2012, p. 1261), Ngain atau normalized gain adalah perban- 
dingan gain rata-rata sebenarnya dengan gain rata-rata maksimum.

Pengambilan kesimpulan terhadap efektivitas $e$-book interaktif mata pelajaran TIK tersebut dilakukan menggunakan uji beda dengan menggunakan independent $t$ test (2-tailed). Terdapat persyaratan sebelum data uji menggunakan independent t-test (2-tailed). Persyaratannya adalah sebagai berikut: (a)uji normalitas, digunakan untuk menentukan data yang telah dikumpulkan berdistribusi normal atau memiliki sebaran normal. Uji normalitas dilakukan dengan uji Kolmogorov-Smirnov dan Shapiro-Wilk dengan bantuan aplikasi SPSS. Data dapat dikatakan berdistribusi normal jika nilai sig lebih dari taraf signifikansi 0,05; (b) uji homogenitas, digunakan untuk mengetahui apakah data diperoleh dari populasi yang tidak jauh berbeda keseragamannya. Uji homogenitas dilakukan dengan uji Lavene dengan ban-tuan aplikasi SPSS. Data dapat dikatakan homogen apabila nilai sig lebih besar dari taraf signifikansi 0,05.

Pengambilan keputusan mengenai efektivitas multimedia pembelajaran e-book interaktif TIK adalah berdasarkan hasil uji independent t-test (2-tailed) terhadap hipotesis berikut:

$H_{0}$ : Rerata skor N-gain pretest dan posttest peserta didik pada kelas eksperimen dan kelas kontrol adalah identik (sama).

$H_{1}$ : Rerata skor N-gain pretest dan posttest peserta didik pada kelas eksperimen dan kelas kontrol adalah tidak identik (berbeda).

Ktiteria uji terhadap hipotesis tersebut adalah $H_{0}$ akan diterima apabila nilai probabilitasnya (Sig.) $>$ taraf signifikansi ( $\alpha$ ) 0,05 dan $H_{0}$ akan ditolak apabila nilai probabilitasnya (Sig.) < taraf signifikansi $(\alpha)$ 0,05 .

\section{Hasil Penelitian dan Pembahasan}

Hasil Validasi Produk

Kegiatan uji coba meliputi uji alpha dan uji beta. Uji alpha dilakukan oleh 2 orang ahli materi dan 2 orang ahli media. Sedangkan pada uji beta dilakukan oleh 26 orang peserta didik kelas X-MM1 yang dianggap mewakili calon pengguna $e$-book interaktif kelas X SMK N 2 Yogyakarta. Kelas X-MM1 dipilih sebagai peserta uji beta setelah dilakukan brainstorming dengan pendidik mata pelajaran Perakitan Komputer yang bersangkutan.

Ahli materi melakukan evaluasi dari aspek materi dan konten dan ahli media melakukan evaluasi dari aspek media. Hasil evaluasi ahli materi dan ahli media akan dijadikan bahan dan masukan untuk melakukan revisi e-book interaktif . Setelah dilakukan evaluasi terhadap evaluasi uji alpha, selajutnya dilakukan uji beta. Hasil uji beta dijadikan bahan revisi untuk memperoleh e-book interaktif yang dikategorikan layak untuk digunakan dalam pembelajaran.

Data validasi terhadap ahli materi diperoleh melalui lembaran instrumen ahli materi dengan penilaian berskala Likert yang terdiri dari aspek kualitas materi dengan 30 indikator. Ahli materi memberikan penilaian terhadap bahan ajar, silabus, Rencana Pelaksanaan pembelajaran (RPP), kisi-kisi soal evaluasi, serta produk e-book interaktif TIK. Berdasarkan pengamatan terhadap produk e-book interaktif, ahli materi memberikan penilaian dengan cara mengisi lembar validasi dan memberikan koreksi serta saran untuk perbaikan e-book interaktif yang dikembangkan. Hasil penilaian ahli materi terhadap e-book interaktif TIK disajikan pada Tabel 2.

Tabel 2. Rerata Skor Hasil Validasi Ahli Materi

\begin{tabular}{cccc}
\hline No & Aspek & Rerata & Kriteria \\
\hline 1 & $\begin{array}{c}\text { Kualitas materi } \\
\text { Rerata }\end{array}$ & 4,275 & Sangat Baik \\
\hline \multicolumn{3}{c}{ Sumber : pengolahan data }
\end{tabular}

Berdasarkan rerata skor hasil validasi ahli materi 1 dan ahli materi 2 tersebut diketahui bahwa aspek kualitas materi secara keseluruhan mendapatkan skor rata- 
rata 4,275 sehingga dikategorikan sangat baik untuk digunakan.

Selain hal tersebut, ahli materi juga menyatakan bahwa secara umum e-book interaktif TIK layak untuk dilakukan uji coba. Ahli materi 1 menyatakan layak digunakan dengan revisi sesuai saran serta memberikan koreksi diantara perlu digunakannya buku reverensi tambahan lain sebagai penguat sumber materi yang akan dibahas pada e-book interaktif tersebut. Selain itu, perlu ditambahkan animasi dan navigasi untuk menambah interaktif ketika diuji cobakan. Ahli materi 2 menyatakan layak digunakan revisi sesuai saran diantaranya agar gambar dalam e-book interaktif diperbesar, hilangkan beberapa animasi yang tidak diperlukan, dan sesuaikan background dengan warna teks agar mudah dibaca. Selain itu, perlu diperbaiki beberapa istilah tentang Teknologi Informasi dan Komunikasi yang digunakan pada $e$ book interaktif tersebut

Data validasi ahli media diperoleh melalui lembar instrumen ahli media dengan penilaian berskala Likert yang terdiri dari aspek pengenalan aplikasi, kontrol pengguna, tampilan aplikasi, bantuan aplikasi, akhir aplikasi, dan prinsip desain multimedia. Ahli media memberikan penilian terhadap tampilan dan komponenkomponen multimedia yang digunakan. Berdasarkan pengamatan terhadap produk multimedia e-book intekatif tersebut, ahli media memberikan penilaian dan memberikan koreksi serta saran untuk perbaikan produk yang dikembangkan. Hasil penilaian ahli media terhadap e-book interaktif TIK disajikan pada Tabel 3.

Tabel 3. Rerata Skor Hasil Validasi Ahli Media

\begin{tabular}{clcc}
\hline No & \multicolumn{1}{c}{ Aspek } & Rerata & Kriteria \\
1 & Pengenalan aplikasi & 4,25 & Sangat Baik \\
2 & Kontrol pengguna & 4,33 & Sangat baik \\
3 & Tampilan aplikasi & 4,32 & Sangat baik \\
4 & Bantuan aplikasi & 4 & Baik \\
5 & Akhir aplikasi & 4,16 & Sangat baik \\
6 & Prinsip desain multimedia & 4 & Baik \\
& Rerata & 4,216 & Sangat baik \\
\hline
\end{tabular}

Sumber : pengolahan data
Berdasarkan rata-rata skor hasil validasi ahli media 1 dan ahli media 2 tersebut diketahui bahwa aspek pengenalan aplikasi mendapatkan skor 4,25 sehingga komponen pengenalan awal program multimedia tersebut dapat dikategorikan "Sangat Baik", aspek kontrol pengguna mendapatkan skor 4,33 sehingga komponen konrol yang berfungsi sebagai navigasi dapat dikategorikan "Sangat Baik", aspek tampilan aplikasi program mendapatkan skor 4,32 sehingga gaya penyajian yang dimiliki multimedia tersebut dikategorikan "Sangat Baik", aspek bantuan aplikasi program mendapatkan skor 4 sehingga pemberian bantuan cara belajar dan pengoperasian pada multimedia tersebut dapat dikategorikan "Baik", aspek akhir aplikasi mendapatkan skor 4,16 sehingga sajian tampilan yang diberikan ketika multimedia tersebut berakhir dapat dikategorikan "Sangat Baik", dan aspek prinsip desain multimedia mendapatkan skor 4 sehingga penerapan prinsip-prinsip desain multimedia pada produk e-book interaktif TIK dapat dikategorikan "Baik". Secara keseluruhan produk multimedia e-book interaktif TIK pada aspek media mendapatkan rata-rata skor 4,216 sehingga dikategorikan sangat baik untuk digunakan.

Uji beta merupakan uji produk akhir yang dilakukan oleh target pengguna produk multimedia e-book interaktif TIK yaitu peserta didik kelas X SMK N 2 Yogyakarta jurusan Multimedia. Uji beta dilaksanakan secara formal dengan prosedur pembelajaran yang telah disetujui pada rencana pelaksanaan pembelajaran. Uji beta dilakukan setelah dilakukan revisi produk dari uji yang telah dilaksanakan oleh ahli materi dan ahli media. Uji Beta ini bertujuan untuk mendapatkan masukan dan penilaian dari peserta didik yang akan digunakan sebagai dasar untuk melakukan penyempurnaan produk sehingga produk multimedia e-book interaktif TIK dapat dikatakan baik dan layak digunakan sebagai sumber belajar TIK secara luas. Peserta pada uji beta adalah kelas X MM-1 
yang berjumlah 26 peserta didik. Hasil uji beta tersebut disajikan pada Tabel 4 .

Tabel 4. Hasil Rekapitulasi Data Uji Beta

\begin{tabular}{clrl}
\hline No & \multicolumn{1}{c}{ Aspek } & Rerata & Kriteria \\
1 & Kemudahan & 4,32 & Sangat Baik \\
& penggunaan aplikasi & & \\
2 & Tampilan aplikasi & 4,10 & Sangat baik \\
3 & $\begin{array}{l}\text { Kemudahan aplikasi } \\
\text { dipelajari isinya }\end{array}$ & 4,25 & Sangat baik \\
& \multicolumn{1}{c}{ Rerata } & 4,209 & Sangat baik \\
\hline
\end{tabular}

Sumber : pengolahan data

Berdasarkan data tanggapan atau respon peserta didik terhadap produk multimedia e-book TIK yang disajikan pada Tabel 4 menunjukan bahwa produk multimedia e-book TIK dari aspek kemudahan dioperasikan diperoleh skor 4,32 sehingga dapat dikategorikan "Sangat Baik", kemudian dari aspek tampilan aplikasi diperoleh skor 4,10 sehingga dapat dikategorikan "Sangat Baik", serta dari aspek kemudahan aplikasi dipelajari isinya diperoleh skor 4,25 sehingga dapat dikategorikan "Sangat Baik". Produk multimedia e-book interaktif yang dikembangkan secara keseluruhan memperoleh skor 4,2 sehingga dapat dikategorikan "Sangat Baik". Meskipun demikian produk masih memiliki beberapa kekurangan yang perlu diperbaiki sebagaimana atas saran dan komentar dari peserta didik. Dengan demikian dapat disimpulkan bahwa produk multimedia $e$-book interaktif TIK memiliki kualitas yang baik sehingga layak untuk dapat digunakan sebagai sumber belajar TIK secara luas.

\section{Hasil Revisi Produk}

Produk yang telah diuji coba melalui uji alpha dan uji beta mendapatkan sejumlah revisi atau rekomendasi untuk perbaikan produk multimedia pembelajaran. Tujuan dilakukannya revisi atau perbaikan produk ialah agar produk yang dihasilkan dapat digunakan oleh pengguna secara layak dan berkualitas. Berdasarkan data deskriptif yang diperoleh dari ahli materi dan ahli media maka dilakukan revisi tahap pertama, berupa penambahan buku reverensi, penambahan animasi agar lebih interaktif, hilangkan animasi yang tidak diperlukan, penambaha video sebagai penunjang pembelajaran, penambahan quiz sebagai evaluasi, gambar perlu diperbesar ukurannya.

Suatu media pembelajaran memiliki suatu karakteristik yang menentukan kualitas suatu media. Adapun karakteristik multimedia yang mempengaruhi tampilan, kegunaan, dan efektifitas suatu software disampaikan Munir (2013)terdiri dari beberapa komponen antara lain: kejelasan tujuan pembelajaran, ketepatan tujuan pembelajaran, kesesuaian antara tujuan pembelajaran dan materi, ketepatan materi yang digunakan dalam multimedia, kesetimbangan antara paparan konsep dan contoh, dan kesesuaian antara materi dengan tingkat pemahaman siswa.

Revisi pada tahap kedua dilakukan setelah diperoleh data deskriptif berupa masukan dari peserta didik. Berdasarkan data tersebut maka dilakukan perbaikan berupa peningkatan kontras pada petunjuk, penambahan beberapa istilah penjelas, soal pada evaluasi perlu ditambahkan.

\section{Hasil Uji Coba Produk}

Perolehan hasil tes siswa juga dapat mendukung penilaian kelayakan produk seperti penelitan yang telah dilaksanakan (Mawarni \& Muhtadi, 2017, p. 87). Data hasil uji coba lapangan untuk menilai hasil belajar yang dilakukan di sekolah dengan memberikan pretest dan posttest pada dua kelas yang berbeda yaitu pada kelas eksperimen dan kelas kontrol. Kelas yang digunakan sebagai kelas eksperimen adalah kelas X MM-1, sedangkan sebagai kelas kontrol adalah kelas X MM-2. Perbedaan kelas uji efektivitas tersebut dengan kelas uji coba produk dimasukkan agar subyek berangkat dari kondisi yang sama yakni belum diberikan perlakuan atau pengalaman menggunakan produk multimedia e-book komputer TIK sehingga data yang diperoleh lebih valid dan seimbang. 
Data yang digunakan dalam menguji hipotesis ini adalah skor N-gain kelompok eksperimen dan kelompok kontrol. Rekapitulasi hasil pretest, posttest, dan $\mathrm{N}$ gain kelas eksperimen dan kelas kontrol disajikan pada Tabel 5.

Tabel 5. Hasil Pretest, Posttest, dan N-gain

\begin{tabular}{ccc}
\hline & Eksperimen & Kontrol \\
\hline Pretest & 55,85 & 58,29 \\
Posttest & 87,23 & 81,57 \\
$N$-gain & 0,72 & 0,56 \\
\hline
\end{tabular}

Sumber: pengolahan data

Data N-gain pretest postest kelas eksperimen dan kelas kontrol perlu dilakukan uji normalitas dan uji homogenitas terlebih dahulu sebagai uji prasyarat agar selanjutnya dapat dilakukan berbagai uji.

Uji normalitas dilakukan sebelum pengujian hipotesis untuk mengetahui apakah data berdistribusi normal atau tidak. Uji normalitas ini menggunakan Kolmogorov-Smirnov test pada SPSS. Uji normalitas data $\mathrm{N}$-gain pretest posttest kelas eksperimen dan kelas kontrol disajikan pada Tabel 6 .

Tabel 6. Hasil Uji Normalitas Skor N-gain Pretest Posttest Kelas Eksperimen dan Kelas Kontrol

\begin{tabular}{lcc}
\hline & Eksperimen & Kontrol \\
\hline Statistic & 0,110 & 0,113 \\
Df & 26 & 28 \\
Sig (p) & 0,200 & 0,200 \\
\hline
\end{tabular}

Sumber : pengolahan data

Berdasarkan hasil uji normalitas data N-gain diperoleh $p>(a)$ 0,05 untuk kedua kelas yaitu kelas eksperimen sebesar 0,200 dan kelas kontrol sebesar 0,200 sehingga kedua data tersebut berdistribusi normal. Dengan demikian, data tersebut dapat digunakan untuk uji statistik selanjutnya yaitu uji homogenitas dan uji perbedaan.

Uji homogenitas dilakukan sebelum hipotesis dan berfungsi untuk mengetahui apakan variansi kedua kelompok sama atau tidak. Uji homogenitas tersebut dicari menggunakan uji SPSS. Uji homogenitas data pretest dan data posttest kelas eksperimen dan kelas kontrol dissajikan pada Tabel 7.

Tabel 7. Hasil Uji Homogenitas Skor Ngain Pretest Posttest kelas Eksperimen dan Kelas Kontrol

\begin{tabular}{lc}
\hline \multicolumn{2}{c}{ Test of Homogenity of Varience } \\
\hline Levene Statistic & 0,110 \\
df1 & 26 \\
df2 & 0,200 \\
Sig(p) & 0,619 \\
\hline Sumber : pengolahan data
\end{tabular}

Sumber : pengolahan data

Hasil uji homogenitas skor $N$-gain pretest posttest kelas eksperimen dan kelas kontrol menunjukkan bahwa p > (a) 0,05 dan dapat disimpulkan bahwa data $\mathrm{N}$-gain pretest posttest kelas eksperimen dan kelas kontrol berasal dari varian yang homogen.

Setelah diketahui data $N$-gain pretest posttest kelas eksperimen dan kelas kontrol berdistribusi normal dan berasal dari varian yang sama (homogen), langkah selanjutnya adalah melakukan uji perbedaan menggunakan independent sample $t$ test terhadap $N$-gain pretest posttest kelas eksperimen dan kelas kontrol untuk membuktikan hipotesis. Hasil uji tersebut disajikan pada tabel 8 .

Tabel 8. Hasil Rekapitulasi Uji-t

\begin{tabular}{ccccc}
\hline No & Aspek & $\begin{array}{r}\text { Hasil } \\
\text { uji t }\end{array}$ & $\begin{array}{c}\text { Nilai } \\
\text { Sig }\end{array}$ & Keterangan \\
\hline 1 & $\begin{array}{l}\text { N-gain kelas eksperi- } \\
\text { men dan kontrol }\end{array}$ & 4,32 & 0,000 & Signifikan \\
\hline \multicolumn{3}{c}{ Sumber : pengolahan data }
\end{tabular}

Berdasarkan uji menggunakan independent sample t test pada aplikasi SPSS yang selanjutnya diuji signifikansinya dengan menggunakan taraf signifikasi sebesar $5 \%$ diperoleh $p=0,000$ atau Sig. < (a) 0,05 sehingga dapat disimpulkan bahwa $\mathrm{H}_{0}$ ditolak berarti terdapat perbedaan rata-rata skor $N$-gain pretest posttest peserta didik pada kelas eksperimen setelah diberikan produk e-book interaktif TIK dan kelas kontrol. 
Berdasarkan Tabel 4 dapat dilihat nilai maksimum, nilai minimum dan rerata $N$-gain pretest posttest kelas eksperimen lebih tinggi dibandingkan dengan kelas kontrol. Nilai minimum pada kelas ekspe-rimen adalah 0,50 sedangkan pada kelas kontrol adalah 0,30 . Nilai maksimum pada kelas eksperimen adalah 0,89 sedangkan pada kelas kontrol adalah 0,78 . Kemudian rerata $\mathrm{N}$-gain pada kelas eksperimen ada-lah 0,72 sedangkan pada kelas kontrol ada-lah 0,56 dan dapat dikatakan bahwa $N$-gain kelas eksperimen lebih tinggi dibanding-kan dengan $N$-gain kelas kontrol. Kebermanfaatan produk dalam hasil belajar dapat diketahui dari perhitungan nilai gain (gain ternormalisasi atau N-gain) post test terhadap pre test seperti penelitan yang telah dilaksanakan Satrio \& Gafur (2017, p. 3). Berdasarkan pada keputusan uji statistik tersebut dapat disimpulkan bahwa peningkatan skor/nilai hasil belajar pembelajaran TIK menggunakan produk e-book interaktif TIK lebih tinggi daripada pembelajaran TIK biasa.

Keefektifan penggunaan e-book interaktif TIK dapat diketahui dengan melakukan penilaian terhadap hasil belajar peserta didik. Uji efektivitas dilakukan dengan metode eksperimental yakni membandingkan antara kelas yang menggunakan $e$-book interaktif TIK dengan kelas yang tidak menggunakan e-book interaktif TIK. Penilaian terhadap hasil belajar peserta didik dilakukan dengan memberikan pretest dan posttest terhadap kelas eksperimen dan kelas kontrol. Berdasarkan uji menggunakan independent sample t test pada SPSS yang selanjutnya diuji signifikansinya dengan menggunakan taraf signifikansi 5\% diperoleh nilai $\mathrm{p}=0,000$ dan dapat disimpulkan $\mathrm{H}_{0}$ ditolak atau rerata $\mathrm{N}$-gain pretest postest kelas eksperimen dan kontrol berbeda signifikan. Rerata $N$-gain pada kelas kontrol 0,56 sedangkan pada kelas eksperimen adalah 0,72 sehingga dapat dikatakan bahwa $N$-gain kelas eksperimen lebih tinggi dibandingkan $\mathrm{N}$-gain kelas kontrol. Hal ini menunjukkan e-book interaktif TIK dapat dikatakan efektif digunakan dalam pem- belajaran. Penggunaan e-book interaktif dalam pembelajaran berdampak pada peningkatan capaian hasil belajar peserta didik.

Efektivitas e-book interaktif TIK dapat dicapai juga berkat penerapan strategi instruksional seperti kegiatan menarik perhatian melalui penggunaan berbagai kombinasi antara teks, gambar, suara, dan video/animasi, selain itu penggunaan warna yang cerah dapat menarik perhatian serta memberikan efek semangat kepada peserta didik. Hal tersebut juga didukung dengan tampilan dan pengoperasian produk yang mudah dipahami dengan menerapkan prinsip multimedia yang dikemukakan Mayer (2009) yang terdiri dari prinsip multimedia, keterdekatan ruang dan waktu, modalitas, koherensi, dan redundansi Selain itu, pemberian tujuan pembelajaran juga menjadikan peserta didik memahami hal-hal apa saja yang perlu dicapai sehingga peserta didik mengetahui arah pembelajaran melalui e-book interaktif TIK berbassis multimedia. Penyajian isi dari e-book interaktif TIK juga menggunakan kalimat yang komunikatif serta mudah dipahami sehingga memudahkan peserta didik menerima pesan yang disampaikan. Pemberian bimbingan belajar pada e-book interaktif ialah berupa petunjuk penggunaan kepada peserta didik agar mereka mengetahui bagaimana mereka menggunakan e-book interaktif TIK.

\section{Simpulan}

Berdasarkan hasil pengembangan dan penelitian, maka dapat disimpulkan antara lain sebagai berikut.

Pertama, Multimedia pembelajaran e-book interaktif TIK merupakan produk yang dikembangkan sebagai media pembelajaran mata pelajaran TIK perakitan komputer kelas X jurusan Multimedia SMK N 2 Yogyakarta. Uji kelayakan produk dilakukan sebanyak dua jenis uji yaitu uji alfa dan uji beta. Uji alfa dilakukan oleh 2 ahli materi dan 2 ahli media. Rata-rata penilaian ahli materi terhadap produk mul-timedia $e$ book interaktif TIK adalah sebesar 4,275 atau 
dikategorikan "Sangat Baik", sedangkan rata-rata penilaian ahli media adalah sebesar 4,216 atau dikategorikan "Sangat Baik". Uji beta dilakukan oleh pe-serta didik kelas X SMK N 2 Yogyakarta. Rata-rata penilaian oleh peserta didik atau pengguna adalah sebesar 4,209 atau dikate-gorikan "Sangat Baik". Dengan demikian produk multimedia e-book interaktif TIK memiliki kualitas baik sehingga layak digunakan untuk kegiatan pembelajaran.

Kedua, Efektivitas e-book interaktif TIK terhadap pembelajaran diuji menggunakan metode eksperimental/quasiexperiment. Uji efektivitas dilakukan setelah uji kelayakan produk multimedia pembelajaran. Pelaksanakan uji efektivitas tersebut didasarkan hasil uji $\mathrm{t}$ (t-test) pada nilai pretest dan postest 2 kelas yaitu kelas eksperimen dan kelas kontrol. Terdapat perbedaan hasil belajar antara kelas eksperimen dan kelas kontrol setelah pembelajaran dengan nilai $\mathrm{p}=0,000$. Rerata N-gain pada kelas kontrol 0,56 sedangkan pada kelas eksperimen 0,78. Nilai N-gain antara kelas eksperimen dan kelas kontrol menunjukan bahwa nilai kelas eksperimen lebih tinggi daripada kelas kontrol dan berbeda secara signifikan

Berdasarkan hasil penelitian yang sudah disajikan dapat disarankan hal-hal sebagai berikut:

Pertama, E-book interaktif TIK ini perlu diimplementasi lebih lanjut agar diketahui kelemahan dan kekurangannya dalam proses pembelajaran. Pemanfaatan $e$ book interaktif TIK tersebut dapat digunakan sebagai pendamping sumber belajar yang lain. E-book interaktif dapat digunakan untuk guru sebagai media pembelajaran dan dapat digunakan pula sebagai sumber belajar bagi peserta didik untuk kegiatan belajar mandiri. Kedua, mata pelajaran yang dikemas dalam bentuk e-book interaktif tidak hanya untuk TIK khususnya perakitan kompter saja, akan tetapi masih perlu adanya pengembangan e-book interaktif untuk mata pelajaran lainnya. Ketiga, materi TIK khususnya perakitan komputer perlu ditambahkan agar pembel- ajaran dalam satu semester maupun satu tahun pembelajaran bisa dibantu secara menyeluruh dengan mengguanakan e-book interaktif tersebut.

\section{Daftar Pustaka}

Alessi, S. M., \& Trollip, S. P. (2001). Multimedia for learning: methods and development (3rd ed.). Boston: Allyn and Bacon.

Mawarni, S., \& Muhtadi, A. (2017). Pengembangan digital book interaktif mata kuliah pengembangan multimedia pembelajaran interaktif untuk mahasiswa teknologi pendidikan. Jurnal Inovasi Teknologi Pendidikan, 4(1), 84. https:// doi.org/10.21831/jitp.v4i1.10 114

Mayer, R. E. (2009). Multimedia learning prinsip-prinsip dan aplikasi. (Terjemahan Teguh Wahyu Utomo). (C. U. Press, Ed.). New York.

Meltzer, D. E. (2012). The reliationship between mathematics preparation and conceptual learning gains in physics: A possible "Hidden Variable" in Diagnostic Pretest Scores. . American Journal of Physics, 70(12), 1259-1268.

Munir. (2013). Multimedia dan konsep aplikasi dalam pendidikan. Bandung: Alfabeta.

Rusman, Deni Kurniawan, \& Cepi Riyana. (2013). Pembelajaran berbasis teknologi informasi dan komunikasi: mengembangkan profesionalitas guru. Jakarta: Rajawali Pers.

Satrio, A., \& Gafur, A. (2017). Pengembangan visual novel game mata pelajaran ilmu pengetahuan sosial di sekolah menengah pertama. Jurnal Inovasi Teknologi Pendidikan, $4(1), 1$.

https:// doi.org/10.21831/jitp.v4i1.10 140

Shiratuddin, N., Landoni, M., Gibb, F., \& Hassan, S. (2003). E-book technology 
and its potential applications in distance education. Journal of Digital Information, 3(4). Retrieved from https://journals.tdl.org/jodi/index.p hp/jodi/article/view/90/89

Sudijono, A. (2013). Pengantar evaluasi pendidikan. Jakarta: PT Rajagrafindo Persada.

Sujarwo. (2011). Model-model pembelajaran.
Yogyakarta: Venus Gold Press.

Surahman, E., \& Surjono, H. D. (2017). Pengembangan adaptive mobile learning pada mata pelajaran biologi SMA sebagai upaya mendukung proses blended learning. Jurnal Inovasi Teknologi Pendidikan, 4(1), 26. https:// doi.org/10.21831/jitp.v4i1.97 23 